\title{
Pengaruh model pembelajaran blended learning terhadap pemahaman konsep dan kelancaran prosedur matematis
}

\author{
Dewa Gede Agung Putra Nugraha *, I Wayan Puja Astawa, I Made Ardana \\ Jurusan Pendidikan Matematika, Universitas Pendidikan Ganesha. Singaraja, Bali, 81111, Indonesia. \\ E-mail: putranugraha1085@gmail.com \\ * Corresponding Author
}

\begin{tabular}{l} 
ARTICLE INFO \\
\hline Article history \\
Received: 25 June 2018; \\
Revised: 2 September 2018; \\
Accepted: 28 August 2019 \\
Keywords \\
pemahaman konsep; \\
kelancaran prosedur; \\
blended learning; Edmodo; \\
conceptual understanding; \\
procedural fluency; blended \\
learning model
\end{tabular}

\section{ABSTRACT}

Penelitian ini bertujuan untuk mendeskripsikan pengaruh penerapan model blended learning terhadap pemahaman konsep dan kelancaran prosedur matematis siswa. Penelitian ini merupakan eksperimen semu dengan rancangan posttest only control group design. Populasi penelitian mencakup seluruh siswa kelas VIII SMP Negeri 1 Sukawati tahun pelajaran 2017/2018. Sampel penelitian sebanyak 2 kelas dipilih menggunakan teknik simple random sampling. Model pembelajaran blended learning yang digunakan dalam penelitian ini adalah flipped classrrom model dengan Edmodo yang digunakan sebagai media pendukung dalam pembelajaran online. Pemahaman konsep dan kelancaran prosedur matematis diukur menggunakan tes berbentuk soal uraian yang valid dan reliabel. Selanjutnya data yang diperoleh dianalisis menggunakan uji MANOVA dengan taraf signifikan 5\% $(\alpha=0,05)$. Hasil pengujian hipotesis menunjukkan bahwa pembelajaran blended learning berpengaruh positif terhadap pemahaman konsep dan kelancaran prosedur matematis siswa.

This study aimed to describe the effect of implementing a blended learning model toward mathematical conceptual understanding and procedural fluency. This study was quasi-experimental research with a posttest only control group design. The population in this study includes all student 8th grade of SMP Negeri 1 Sukawati, Indonesia in the academic year 2017/2018. Two class as samples were obtained by using simple random sampling technique. Blended learning model used in this study was a flipped classroom model with Edmodo which used as supporting online learning. Mathematical conceptual understanding and procedural fluency were measured by a test that has been valid and reliable. Furthermore, the data obtained were analyzed by using the MANOVA test with 5\% significance level $(\alpha=0.05)$. The results of the hypothesis test showed that the blended learning model has a positive effect on students' mathematical conceptual understanding and procedural fluency.

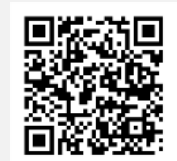

How to Cite: Nugraha, D. G. A. P., Astawa, I. W. P., \& Ardana, I. M. (2019). Pengaruh model pembelajaran blended learning terhadap pemahaman konsep dan kelancaran prosedur matematis. Jurnal Riset Pendidikan Matematika, 6(1), 75-86. doi:https://doi.org/10.21831/jrpm.v6i1.20074

\section{PENDAHULUAN}

Matematika memegang peranan yang sangat penting bagi siswa dan masyarakat pada umumnya. Di sekolah, matematika diperlukan untuk berhitung, melakukan pengukuran, mengolah, menyajikan serta menafsirkan data dan lain sebagainya. Di tempat lain, matematika diperlukan pada saat berdagang maupun berbelanja, membaca informasi yang disajikan berupa angka, tabel, diagram maupun persen. 
Karena memiliki manfaat yang penting dalam kehidupan dan diperlukan sebagai dasar untuk mempelajari matematika lanjut dan pelajaran lainnya, matematika menjadi mata pelajaran yang penting untuk diajarkan di sekolah.

Mengingat pentingnya peranan matematika dalam kehidupan manusia dan pengembangan pengetahuan, sudah sepantasnya penguasaan konsep-konsep matematika dilakukan dan harus dipahami dengan tepat dan benar. Selain itu, dalam matematika memahami suatu konsep merupakan prasyarat untuk memahami konsep selanjutnya. Menurut Kilpatrick, Swafford, dan Findell (Afrilianto, 2012, p.2) pemahaman konsep matematika merupakan salah satu kecakapan matematis yang harus dikuasai siswa dalam pembelajaran matematika. Kilpatrick et al. (Afrilianto, 2012, p.196) mengemukakan bahwa pemahaman konsep matematika (conceptual understanding) adalah kemampuan dalam memahami konsep, operasi dan relasi dalam matematika. Danley (2008) berpendapat bahwa pemahaman konsep matematika bukan hanya pengetahuan tentang konsep yang tidak berhubungan, tetapi juga kemampuan untuk menjelaskan hubungan di antara mereka. Pemahaman konsep yang kuat dalam matematika sangat membantu siswa dalam memahami suatu pokok bahasan matematika. Setelah siswa mampu memahami konsep, barulah diperlukan keterampilan untuk menggunakan konsep tersebut. Oleh karena itu siswa harus memahami konsep-konsep matematika sebelum memiliki keterampilan dalam memecahkan soal ataupun mampu menggunakan apa yang telah mereka pelajari untuk menyelesaikan permasalahan dalam kehidupan sehari-hari. Pembekalan konsep yang kuat dalam matematika merupakan tonggak utama dan sangat membantu bagi siswa dalam memahami suatu pokok bahasan matematika. Berkaitan dengan hal itu, pemahaman konsep matematika di jenjang SMP mutlak diperhatikan dan penguasaan terhadap konsep matematika di jenjang ini akan menjadi prasyarat penting untuk mempelajari matematika di jenjang pendidikan selanjutnya.

Hal penting lainnya yang juga harus diperhatikan adalah kelancaran prosedur. Kelancaran prosedur adalah kemampuan untuk memecahkan masalah dengan menggunakan prosedur yang efisien, akurat, benar untuk menambah, mengurangi, mengalikan dan membagi (Askew, 2012). Winkel (Rustiah, 2011, p.13) menyatakan bahwa belajar keterampilan prosedur menghasilkan kemampuan untuk mengklasifikasikan objek dan kemampuan untuk melakukan serangkaian langkah operasional terhadap suatu obyek. Siswa dengan kelancaran prosedur yang baik dapat menemukan prosedur yang efektif dan efisien untuk mereka sendiri melalui proses berpikir (Bahr \& Garcia, 2010). Tanpa kelancaran prosedur yang memadai, siswa mengalami kesulitan memperdalam pemahaman mereka tentang ide-ide matematika atau memecahkan masalah matematika. Russel (Bahr \& Garcia, 2010, p.154) membagi tiga aspek kelancaran prosedur. Pertama, efisiensi secara tidak langsung menyatakan bahwa siswa tidak terhenti pada langkah-langkah yang banyak dan tidak kehilangan arah dalam strategi berlogika. Kedua, keakuratan tergantung pada beberapa aspek dari proses pemecahan masalah, termasuk perekaman yang hati-hati, pengetahuan kombinasi bilangan, dan memperhatikan hasil dari pengecekan yang berulang. Ketiga, fleksibelitas memerlukan pengetahuan pendekatan yang lebih dari satu untuk menyelesaikan suatu masalah tertentu. Fleksibel yang dimaksud adalah saat siswa menyelesaian suatu masalah, ia dapat memilih satu di antara strategi maupun metode yang ada secara tepat.

Ketika siswa menyelesaikan suatu masalah matematika, diperlukan keterpaduan antara pemahaman konsep dan kelancaran prosedur yang baik. Menurut National Assessment of Educational Progress (NAEP, 2003) pemahaman konsep dan kalancaran prosedur merupakan fokus utama dalam penilaian matematika dan termasuk dalam learning principle dalam pembelajaran matematika, sebagaimana dikemukan oleh National Council of Teachers of Mathematics (NCTM, 2000) dan menjadi tujuan utama dalam pembelajaran matematika di Sekolah Menengah Pertama (Kementerian Pendidikan dan Kebudayaan Republik Indonesia, 2013). Dengan demikian, pemahaman konseptual dan kelancaran prosedural merupakan aspek penting yang harus dimiliki oleh siswa dalam belajar matematika. Secara umum pemahaman konseptual dimaknai sebagai kemampuan siswa dalam memahami konsep, operasi, dan hubungan keduanya secara terpadu dan fungsional dalam belajar matematika (Van de Walle, 2008; Kilpatrick, Swafford, \& Findell, 2001; NCTM, 2000). Sedangkan kelancaran prosedural merupakan kemampuan siswa dalam menggunakan prosedur secara fleksibel, akurat, dan efisien untuk menyelesaikan tugas-tugas matematika langkah demi langkah (Van de Walle, 2008; Kilpatrick et al, 2001; NAEP, 2003). Hiebert dan Levefre (Cramer, Post, \& Currier, 1993; Hermawan, Samsuri, Kurniawati, Sofyaningsih, \& Prasetyo, 2018) menyatakan bahwa pemahaman konsep yang tidak didukung oleh kelancaran prosedur akan mengakibatkan siswa mempunyai intuisi yang baik tentang suatu konsep tetapi tidak mampu menyelesaikan suatu masalah. Di lain pihak, kelancaran prosedur yang 
tidak didukung oleh pemahaman konsep akan mengakibatkan siswa mahir memanipulasi simbol-simbol tetapi tidak memahami dan mengetahui makna dari simbol tersebut. Kondisi ini memungkinkan siswa dapat memberikan jawaban dari suatu soal (masalah) tanpa memahami apa yang mereka lakukan.

Pada kenyataannya, hasil observasi awal di SMP Negeri 1 Sukawati menunjukkan bahwa keterbatasan waktu dalam pertemuan tatap muka antara guru dan siswa mengakibatkan guru sangat jarang memberikan latihan-latihan soal kepada siswa. Hal ini mengakibatkan kelancaran prosedur siswa kurang maksimal. Kesempatan siswa berdiskusi dengan guru juga kurang maksimal karena keterbatasan waktu dalam pertemuan tatap muka tersebut. Hal ini mengakibatkan pemahaman konsep siswa terhadap materi juga kurang maksimal. Hal tersebut mengindikasikan perlunya terobosan-terobosan yang mampu memberikan kesempatan kepada siswa dan guru untuk melakukan pembelajaran di luar pembelajaran tatap muka di kelas dengan waktu yang lebih banyak bahkan tidak terbatas.Salah satu terobosan yang dapat menjadi solusi bagi permasalahan tersebut adalah dengan penerapan model pembelajaran blended learning.

Blended learning didefinisikan sebagai jenis pembelajaran yang menggabungkan model tatap muka tradisional dengan model e-learning, sehingga dapat menciptakan pengalaman belajar yang lebih kaya (Usta, 2007; Akkoyunlu \& Soylu, 2008). Adas dan Shmais (2011) melihat pembelajaran blended learning sebagai metode yang menciptakan lingkungan belajar yang cocok bagi siswa sekolah menengah. Blended learning yang menggabungkan dua lingkungan belajar ini memberikan banyak keuntungan bagi siswa dan guru (Brown 2003; Singh \& Reed, 2001). Blended learning dapat dilihat sebagai kombinasi dari pembelajaran yang menggabungkan komunikasi berbasis web, video, audio, sinkron, dan asinkron dengan pembelajaran tatap muka (Quevedo, 2011). Prinsip dasar blended learning adalah tatap muka dan online, kegiatan terintegrasi secara optimal ke dalam pengalaman belajar yang unik sesuai dengan konteks dan tujuan pembelajaran (Garrison \& Vaughan, 2008).

Penerapan model pembelajaran blended learning memerlukan bantuan media berbasis komputer (online) yang mampu mendukung kegiatan pembelajaran online. Adapun media yang digunakan dalam penelitian ini adalah Edmodo. Edmodo adalah jaringan media sosial yang dirancang oleh Jeff O'Hara dan Nick Borg pada tahun 2008 yang tersedia di website www.edmodo.com. Edmodo adalah jaringan pendidikan global yang membantu menghubungkan semua peserta didik dengan orang lain dan sumber daya yang dibutuhkan untuk mencapai potensi mereka secara penuh (Ardana, 2016). Edmodo adalah komunitas jejaring sosial yang aman dan menyediakan lingkungan mikro blogging pendidikan bagi guru dan peserta didik yang dapat juga dilihat sebagai sistem manajemen pembelajaran multi-platform (LMS) yang dapat memfasilitasi pendidik untuk mengatur dan mengelola kelas online mereka dengan mudah (Witherspoon, 2011). Edmodo menciptakan lingkungan yang aman bagi guru dan siswa dalam banyak hal dalam pembelajaran seperti kerja sama, umpan balik, dan sebagainya, memberikan siswa kebebasan waktu dan tempat belajar, serta membantu mengontrol siswa dan memungkinkan mereka untuk berbagi pengetahuan dan ide-ide mereka dengan fitur-fitur yang ada di dalamnya. Edmodo memungkinkan guru dan siswa untuk berkomunikasi satu sama lain melalui pesan, sehingga memberikan peserta dengan kesempatan untuk berkomunikasi dan berkolaborasi dalam lingkungan kelas virtual (Balasubramanian, Jaykumar \& Fukey, 2014; Ekmekçi, 2016; Mokhtar, 2016). Edmodo adalah salah satu platform sosial pendidikan populer dan paling disukai yang memiliki sekitar 48 juta pengguna di seluruh dunia (National Center for Education Statistics, 2008).

Beberapa hasil penelitian pun menunjukkan bahwa bahwa model pembelajaran blended learning efektif digunakan dalam pembelajaran matematika. Pertama, penelitian yang dilakukan Fatwa dan Djunaidi (2015) menyatakan implementasi model pembelajaran blended learning dapat digunakan sebagai suplemen kegiatan pembelajaran tatap muka, dengan adanya akses belajar secara online dapat menuntaskan penyampaian materi dalam cakupan yang luas dengan kompetensi teori maupun praktik. Kedua, penelitian yang dilakukan Pradnyawati, Suparta dan Sariyasa (2014) menyatakan implementasi model pembelajaran blended learning dapat meningkatkan motivasi belajar matematika. Ketiga, hasil penelitian Eryilmaz (2015) menunjukkan bahwa dalam pembelajaran blended learning, para siswa dapat belajar lebih efektif dalam lingkungan belajar yang terpadu. Keempat, Marhendra, Suryaningtiyas, dan Kristanti (2016) menyatakan pembelajaran blended learning berpengaruh positif dan signifikan terhadap hasil belajar matematika siswa. Meskipun penelitian terkait model blended learning telah banyak dilakukan seperti telah dikemukakan sebelumnya, namun sejauh pengetahuan peneliti belum ada penelitian yang mengkaji bagaimana pengaruh model pembelajaran blended learning terhadap pemahaman konsep dan kelancaran prosedur matematis siswa. Dengan demikian tujuan penelitian 
adalah untuk mendeskripsikan pengaruh model blended learning dalam pembelajaran matematika terhadap pemahaman konsep dan kelancaran prosedur matematis siswa.

\section{METODE}

Penelitian ini merupakan penelitian eksperimen semu (quasi experiment). Penelitian eksperimen semu dapat dilakukan untuk melihat pengaruh yang ditimbulkan dari perlakuan berbeda yang diberikan pada masing-masing kelompok, dimana peneliti tidak mengontrol semua variabel dan kondisi eksperimen secara ketat. Rancangan penelitian ini menggunakan posttest only control group design, sehingga pada pertemuan terakhir kedua kelompok tersebut akan diberikan tes yang sama (posttest), selanjutnya skor dari posttest tersebut digunakan sebagai pedoman dalam melakukan uji hipotesis.

Populasi dalam penelitian ini adalah seluruh siswa kelas VIII SMP Negeri 1 Sukawati, Bali, Indonesia tahun pelajaran 2017/2018 yang terdiri dari 9 kelas. Pengambilan sampel dalam penelitian ini dilakukan secara random dengan sistem pengundian. Kelas dipilih sebagaimana sudah terbentuk tanpa campur tangan peneliti dan tidak dilakukannya pengacakan individu, kemungkinan pengaruh-pengaruh dari keadaan subjek mengetahui dirinya dilibatkan dalam eksperimen dapat dikurangi sehingga penelitian ini benar-benar menggambarkan pengaruh perlakuan yang diberikan. Dari kelas yang diundi dipilih dua kelas secara random sebagai sampel penelitian. Dari kedua kelas tersebut selanjutnya dirandom kembali untuk menentukan satu kelas kontrol dan satu kelas eksperimen. Berdasarkan pengundian yang telah dilakukan, kelas VIII C terpilih sebagai kelas eksperimen dan kelas VIII D sebagai kelas kontrol. Kelas eksperimen diberi perlakuan berupa penerapan model pembelajaran blended lerning dan kelas kontrol diberi perlakuan berupa penerapan pembelajaran konvensional (tidak menggunakan model blended learning). Pada pertemuan terakhir kedua kelas diberi posttest yang sama.

Ada dua jenis variabel yang terlibat dalam penelitian ini, yaitu variabel bebas (independent variable) dan variabel terikat (dependent variable). Variabel bebas dalam penelitian ini adalah model pembelajaran (blended learning vs. konvensional) dan variabel terikat dalam penelitian ini adalah pemahaman konsep dan kelancaran prosedur matematis. Adapun desain penelitian disajikan pada Tabel 1. Berdasarkan Tabel 1 diketahui bahwa $X$ adalah perlakuan berupa penerapan model pembelajaran blended lerning, $\mathrm{Y}_{1}$ adalah post-test pemahaman konsep, dan $\mathrm{Y}_{2}$ adalah post-test kelancaran prosedur.

Tabel 1. Rancangan Penelitian

\begin{tabular}{|c|c|c|}
\hline Kelompok & Perlakuan & Evaluasi \\
\hline \multirow[t]{2}{*}{ Eksperimen } & \multirow{2}{*}{$\mathrm{X}$} & $\mathrm{Y}_{1}$ \\
\hline & & $\mathrm{Y}_{2}$ \\
\hline Kontrol & - & $\begin{array}{l}Y_{1} \\
Y_{2}\end{array}$ \\
\hline
\end{tabular}

Instrumen yang digunakan dalam penelitian ini berupa tes pemahaman konsep dan kelancaran prosedur matematis yang berbentuk uraian. Tes ini digunakan untuk mengukur pemahaman konsep dan kelancaran prosedur siswa dalam materi bangun ruang sisi datar. Pemahaman konsep diukur melalui kemampuan siswa dalam menyatakan ulang konsep yang telah dipelajari dengan kata-kata sendiri, mengidentifikasi yang termasuk contoh atau bukan contoh dari konsep, serta mengaplikasikan konsep dalam berbagai situasi. Kelancaran prosedur diukur melalui kemampuan siswa dalam mengetahui prosedur secara umum, mengetahui kapan dan bagaimana menggunakan prosedur dengan benar, serta menampilkan prosedur secara fleksibel, tepat dan efisien. Teknik penskoran dalam penelitian ini menggunakan rubrik penskoran secara analitik pada masing-masing butir soal. Skor maksimal tes diperoleh dengan cara menjumlahkan skor maksimal tiap butir soal.

Instrumen penelitian akan dikatakan baik jika memenuhi dua persyaratan penting yaitu valid dan reliabel, sehingga perlu dilakukan uji coba instrumen. Uji coba instrumen penelitian dilakukan untuk mendapat gambaran secara empirik apakah instrumen tersebut layak digunakan. Sebelum diberikan kepada siswa yang menjadi sampel penelitian, akan dilakukan beberapa uji terhadap instrumen penelitian untuk mendapatkan tes yang berkualitas. Pertama dilakukan uji pakar/ahli untuk mengetahui validitas isi instrumen. Validasi instrumen dilakukan oleh seorang guru besar dari program studi S2 Pendidikan Matematika Universitas Pendidikan Ganesha (UNDIKSHA) dan seorang guru mata pelajaran matematika di SMP Negeri 1 Sukawati. Masukan dari kedua ahli tersebut diakomodir sampai ahli menyatakan bahwa instrumen telah valid. Selanjutnya tes pemahaman konsep dan kelancaran 
prosedur di uji coba pada kelas IX A SMP Negeri 1 Sukawati untuk mengestimasi reliabilitas instrumen tersebut. Dari hasil estimasi reliabilitas tes diperoleh koefisien reliabilitas instrumen untuk pemahaman konsep dan kelancaran prosedur sebesar 0,809.

Analisis data dilakukan secara deskriptif dan inferensia. Analisis deskriptif dilakukan untuk mendeskripsikan kemampuan rata-rata siswa, standar deviasi, skor maksimum dan minimum. Adapun analisis inferensia digunakan untuk menguji hipotesis penelitian. Sebelum melakukan uji hipotesis, terlebih dahulu dilakukan uji prasyarat yaitu uji normalitas sebaaran data secara univariat, uji normalitas multivariat, uji homogenitas varians, uji homogenitas matriks varians-kovarians, serta uji korelasi antar variabel terikat. Setelah semua uji prasyarat tersebut terpenuhi selanjutnya dilakukan uji hipotesis dengan menggunakan Multivariat Analysis of Variance (MANOVA). Pengujian hipotesis menggunakan taraf signifikan $5 \%(\alpha=0,05)$. Adapun hipotesis yang diuji dalam penelitian ini yaitu:

Hipotesis I (Multivariat):

$$
\begin{aligned}
& \mathrm{H}_{0}:\left[\begin{array}{l}
\mu_{11} \\
\mu_{21}
\end{array}\right]=\left[\begin{array}{l}
\mu_{12} \\
\mu_{22}
\end{array}\right] \begin{array}{l}
\text { (vektor rata-rata pemahaman konsep dan kemampuan prosedur siswa } \\
\text { kelompok eksperimen dan kelompok kontrol adalah sama) }
\end{array} \\
& \mathrm{H}_{1}:\left[\begin{array}{l}
\mu_{11} \\
\mu_{21}
\end{array}\right] \neq\left[\begin{array}{l}
\mu_{12} \\
\mu_{22}
\end{array}\right] \begin{array}{l}
\text { (vektor rata-rata pemahaman konsep dan kemampuan prosedur siswa } \\
\text { kelompok eksperimen dan kelompok kontrol berbeda) }
\end{array}
\end{aligned}
$$

Jika $\mathrm{H}_{0}$ ditolak, maka uji lanjut (posthoc) dilakukan, dengan hipotessis yang akan diuji yaitu sebagai berikut.

\section{Hipotesis II (Univariat)}

$$
\begin{array}{ll}
\mathrm{H}_{0}: \mu_{11}=\mu_{12} & \begin{array}{l}
\text { (tidak terdapat perbedaan rata-rata pemahaman konsep yang signifikan antara } \\
\text { kelompok eksperimen dan kelompok kontrol) } \\
\text { (terdapat perbedaan rata-rata pemahaman konsep yang signifikan antara } \\
\mathrm{H}_{1}: \mu_{11} \neq \mu_{12}
\end{array} \\
\text { kelompok eksperimen dan kelompok kontrol) }
\end{array}
$$

Hipotesis III (Univariat)

$$
\begin{array}{ll}
\mathrm{H}_{0}: \mu_{21}=\mu_{22} & \begin{array}{l}
\text { (tidak terdapat perbedaan rata-rata kemampuan prosedur matematis yang } \\
\text { signifikan antara kelompok eksperimen dan kelompok kontrol) } \\
\text { (terdapat perbedaan rata-rata kemampuan prosedur matematis yang signifikan } \\
\mathrm{H}_{1}: \mu_{21} \neq \mu_{22}
\end{array} \\
\text { antara kelompok eksperimen dan kelompok kontrol) }
\end{array}
$$

\section{HASIL DAN PEMBAHASAN}

Rangkuman hasil analisis deskriptif terhadap skor pemahaman konsep dan kelancaran prosedur matematis siswa pada kelompok eksperimen dan kelompok kontrol seperti tercantum pada Tabel 2 dan Tabel 3. Tabel 2 menunjukkan bahwa rata-rata pemahaman konsep siswa yang diajarkan dengan model blended learning lebih tinggi dibandingkan dengan siswa yang diajar menggunakan model konvensional. Selain itu, ditinjau dari kemampuan prosedur matematis, siswa yang diajar menggunakan model blended learning rata-rata skornya juga lebih tinggi jika dibandingkan dengan siswa yang diajar menggunakan model konvensional. Dengan demikian, secara deskriptif dapat disimpulkan bahwa model blended learning dalam pembelajaran matematika memberikan pengaruh positif terhadap pemahaman konsep matematika dan kemampuan prosedur matematis siswa.

Tabel 2. Rangkuman Hasil Analisis Data Pemahaman Konsep

\begin{tabular}{lcc}
\hline \multirow{1}{*}{ Statistik } & \multicolumn{2}{c}{ Posttest } \\
\cline { 2 - 3 } & Kelompok Eksperimen & Kelompok Kontrol \\
\hline Banyak Siswa & 34 & 34 \\
Rata-rata & 11,088 & 8,882 \\
Simpangan Baku & 3,297 & 3,160 \\
Varians & 10,871 & 9,986 \\
Nilai Maximum & 16 & 15 \\
Nilai Minimum & 6 & 4 \\
\hline
\end{tabular}


Jurnal Riset Pendidikan Matematika, 6 (1), 2019 - 80

Dewa Gede Agung Putra Nugraha, I Wayan Puja Astawa, I Made Ardana

Tabel 3. Rangkuman Hasil Analisis Data Kelancaran Prosedur

\begin{tabular}{lcc}
\hline \multicolumn{1}{c}{ Statistik } & \multicolumn{2}{c}{ Posttest } \\
\cline { 2 - 3 } & Kelompok Eksperimen & Kelompok Kontrol \\
\hline Banyak Siswa & 34 & 34 \\
Rata-rata & 8.029 & 6,323 \\
Simpangan Baku & 2,979 & 2,531 \\
Varians & 8,878 & 6,407 \\
Nilai Maximum & 12 & 12 \\
Nilai Minimum & 2 & 2 \\
\hline
\end{tabular}

Analisis inferensia dilakukan untuk menguji hipotesis penelitian, baik secara multivariat (MANOVA) maupun secara univariat (uji lanjut jika $\mathrm{H}_{0}$ pada uji MANOVA ditolak). Sebelum dilakukan pengujian hipotesis terdapat beberapa asumsi yang harus dipenuhi, yaitu asumsi normalitas, homogenitas, dan korelasi antara variabel terikat. Pengujian normalitas sebaran data pada penelitian ini dilakukan dengan menggunakan uji Kolmogorov-Smirnov pada taraf signifikan 5\% $(\alpha=0,05)$. Hasil analisis uji normalitas disajikan pada Tabel 4.

Tabel 4. Hasil Analisis Uji Normalitas

\begin{tabular}{llccc}
\hline \multirow{2}{*}{ Variabel } & \multirow{2}{*}{ Kelompok } & \multicolumn{3}{c}{ Kolmogorov-Smirnov } \\
\cline { 3 - 5 } & & Statistic & df & p-value \\
\hline Pemahaman Konsep & Eksperimen & 0,149 & 34 & 0,055 \\
& Kontrol & 0,139 & 34 & 0,092 \\
\hline \multirow{2}{*}{ Kelancaran Prosedur } & Eksperimen & 0,128 & 34 & 0,171 \\
& Kontrol & 0,139 & 34 & 0,094 \\
\hline
\end{tabular}

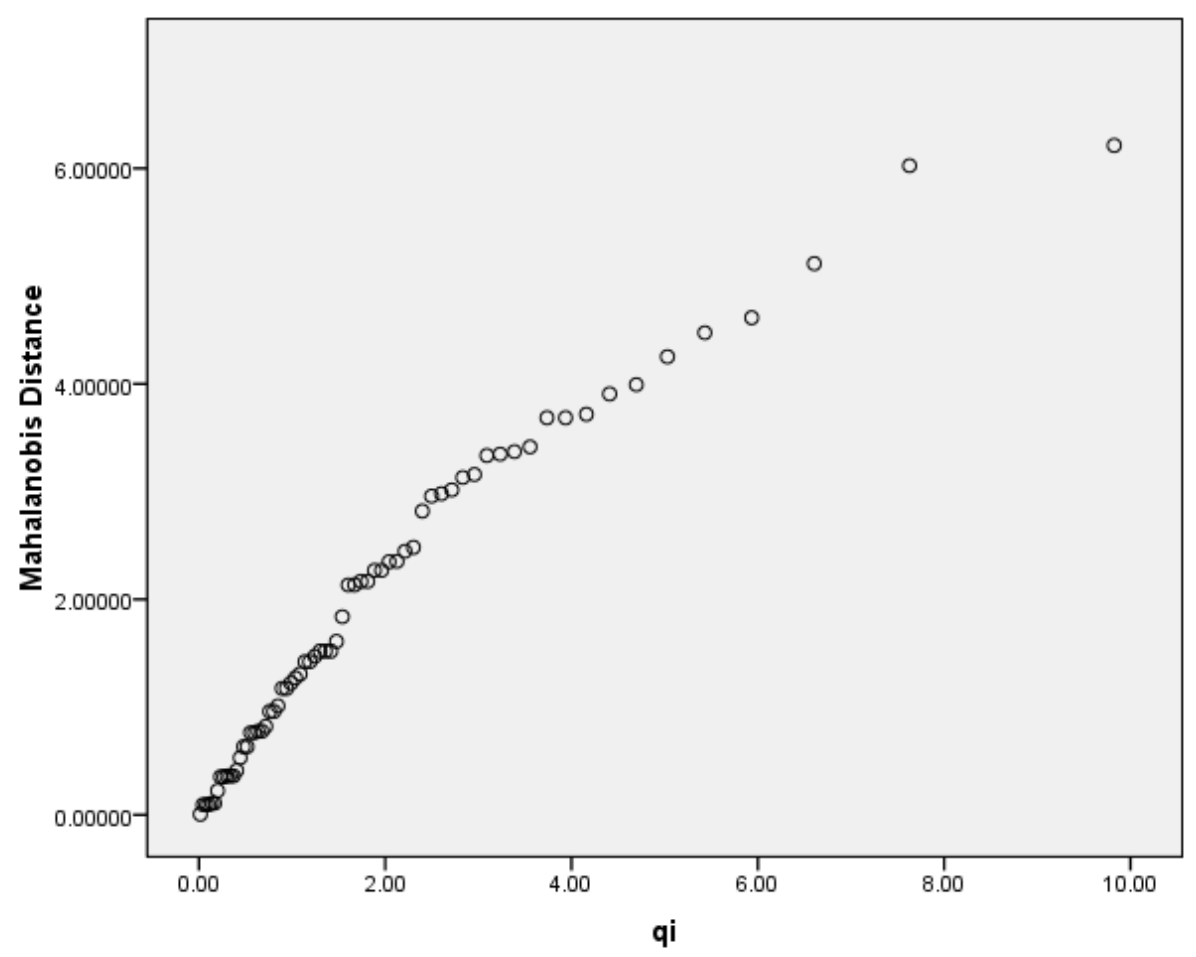

Gambar 1. Grafik Jarak Mahalanobis

Berdasarkan Tabel 4 terlihat bahwa untuk semua kelompok pada masing-masing variabel, nilai $p$-value pada uji Kolmogorov-Smirnov lebih dari 0,05. Dengan demikian dapat disimpulkan bahwa sebaran data untuk masing-masing kelompok pada kedua variabel berdistribusi normal. Selanjutnya dilakukan pengujian normalitas bivariat menggunakan plot chi-square dari distribusi chi-square (qi) dan jarak mahalanobis yang merupakan pendekatan dari normal univariat untuk memperlihatkan normal bivariat pada data. Kenormalan dari dua variabel secara bersamaan dapat juga dilihat dari korelasi antara 
jarak Mahalanobis dengan nilai chi-square. Jika koefisien korelasi lebih besar dari $r_{\text {tabel }}$ atau nilai $p$ value yang diperoleh kurang dari 0.05 maka terdapat korelasi yang signifikan. Hasil pengujian ditunjukkan pada Gambar 1 dan Tabel 5.

Plot qi dan jarak Mahalanobis seperti terlihat pada Gambar 1 menunjukkan bahwa sebaran titiktitik cenderung membentuk suatu pola garis lurus. Hal tersebut mengindikasikan bahwa distribusi normal bivariat terpenuhi. Untuk memperkuat hal tersebut, selanjutnya dilakukan analisis korelasi antara jarak Mahalanobis dan qi yang hasilnya disajikan pada Tabel 5.

Tabel 5. Hasil Analisi Uji Normal Bivariat

\begin{tabular}{llcc}
\hline & & Mahalanobis Distance & qi \\
\hline Mahalanobis Distance & Pearson Correlation & 1 & 0,969 \\
& Sig. (2-tailed) & - & 0,000 \\
& N & 68 & 68 \\
\hline
\end{tabular}

Nilai Pearson Correlation antara Mahalanobis Distance yang diperoleh sebesar 0,969 dengan $p$ value (sig.) $=0,000$, kurang dari 0,05 . Dengan demikian dapat disimpulkan bahwa data berasal dari populasi yang berdistribusi normal bivariat.

Selanjutnya dilakukan pengujian homogenitas varians. Pada penelitian ini, homogenitas varians dari kedua kelompok sampel diuji dengan menggunakan uji Levene pada taraf signifikan $5 \%(\alpha=0,05)$. Hasil uji Levene ditunjukkan ditunjukkan pada Tabel 6.

Tabel 6. Hasil Analisis Uji Homogenitas Kelompok Eksperimen vs. Kontrol

\begin{tabular}{lcccc}
\hline \multicolumn{1}{c}{ Variabel } & F & df1 & df2 & $p$-value \\
\hline Pemahaman Konsep & 0,956 & 1 & 66 & 0,332 \\
\hline Kelancaran Prosedur & 0,841 & 1 & 66 & 0,362 \\
\hline
\end{tabular}

Pada Tabel 6 dapat dilihat bahwa untuk variabel pemahaman konsep nilai $\mathrm{F}_{\text {hitung }}=0,956$ dengan $p$-value 0,332 , sedangkan untuk variabel kelancaran prosedur nilai $\mathrm{F}_{\text {hitung }}=0,841$ dengan $p$-value 0,362 . Karena $p$-value keduanya lebih dari 0,05 , berarti data pemahaman konsep dan kelancaran prosedur untuk kelompok eksperimen dan kelompok kontrol memiliki varians yang homogen. Selanjutnya dilakukan uji homogenitas terhadap matriks varians-kovarians yang dimaksudkan untuk memperlihatkan bahwa matriks varians-kovarians variabel terikat sama. Hasil pengujian terhadap kesamaan matriks varianskovarians disajikan pada Tabel 7.

Tabel 7. Uji Homogenitas Matriks Varians-Kovarian

\begin{tabular}{lcc}
\hline & Statistik & Nilai \\
\hline Box's $M$ & 1,114 \\
F & 0,359 \\
df1 & 3 \\
df2 & 784080,000 \\
$p$-value & 0,783 \\
\hline
\end{tabular}

Tabel 7 menunjukkan bahwa nilai Box's $M=1,114$ dengan $p$-value $=0,783$. Hasil tersebut menunjukkan bahwa matriks varians-kovarians antar variabel terikat adalah homogen. Selanjutnya dilakukan uji korelasi antar variable terikat. Uji korelasi antar variabel terikat dikenakan terhadap sesama variabel terikat yaitu pemahaman konsep dan kelancaran prosedur matematis. Pengujian ini menggunakan korelasi product moment antara sesama variabel terikat. Kaidah yang digunakan untuk menyatakan ada tidaknya korelasi antara sesama variabel terikat adalah dengan membandingkan nilai signifikansi ( $p$-value) yang diperoleh dengan taraf signifikansi yang digunakan dalam penelitian ini yaitu $5 \%(\alpha=0,05)$. Hasil uji korelasi antara kedua variabel terikat untuk kelas eksperimen disajikan pada Tabel 8. 
Jurnal Riset Pendidikan Matematika, 6 (1), 2019 - 82

Dewa Gede Agung Putra Nugraha, I Wayan Puja Astawa, I Made Ardana

Tabel 8. Hasil Analisis Uji Korelasi Variabel Terikat Pada Kelas Eksperimen

\begin{tabular}{llrr}
\hline & & Pemahaman Konsep & Kelancaran Prosedur \\
\hline Pemahaman Konsep & Pearson Correlation & 1 & 0,428 \\
& Sig. (2-tailed) & & 0,011 \\
& $\mathrm{~N}$ & 34 & 34 \\
\hline Kelancaran Prosedur & Pearson Correlation & 0,428 & 1 \\
& Sig. (2-tailed) & 0,011 & 34 \\
& $\mathrm{~N}$ & 34 & 34 \\
\hline
\end{tabular}

Tabel 8 menunjukkan bahwa nilai Pearson Correlation kedua variabel yaitu sebesar 0,428 dengan $p$-value sebesar 0,011 . Nilai $p$-value kurang dari 0,05 menunjukkan bahwa terdapat korelasi signifikan antara pemahaman konsep dan kelancaran prosedur matematis siswa pada kelompok eksperimen. Adapun pada kelompok kontrol, hasil uji korelasi kedua variabel tersebut disajikan pada Tabel 9.

Tabel 9. Hasil Analisis Uji Korelasi Variabel Terikat Pada Kelas Kontrol

\begin{tabular}{llrr}
\hline & & Pemahaman Konsep & \multicolumn{1}{c}{ Kelancaran Prosedur } \\
\hline Pemahaman Konsep & Pearson Correlation & 1 & 0,456 \\
& Sig. (2-tailed) & & 0,007 \\
& $\mathrm{~N}$ & 34 & 34 \\
\hline Kelancaran Prosedur & Pearson Correlation & 0,456 & 1 \\
& Sig. (2-tailed) & 0,007 & 34 \\
& $\mathrm{~N}$ & 34 & 34 \\
\hline
\end{tabular}

Tabel 9 menunjukkan bahwa koefisien korelasi antara kedua variabel sebesar 0,456 dengan $p$ value sebesar 0,007. Hasil tersebut menunjukkan bahwa pemahaman konsep dan kelancaran prosedur matematis pada kelompok kontrol berkolerasi signifikan.

Setelah semua uji prasyarat terpenuhi, maka selanjutnya dilakukan uji hipotesis. Untuk menguji Hipotesis I digunakan Multivariat Analysis of Variance (MANOVA). Hasil uji MANOVA disajikan pada Tabel 10.

Tabel 10. Hasil Analisis MANOVA (Uji Hipotesis I)

\begin{tabular}{llccccc}
\hline \multicolumn{1}{c}{ Effect } & & Value & F & Hypothesis df & Error df & $p$-value \\
\hline Kelompok & Pillai's Trace & 0,132 & 4,946 & 2,000 & 65,000 & 0,010 \\
(Blended vs. Konvensional) & Wilks' Lambda & 0,868 & 4,946 & 2,000 & 65,000 & 0,010 \\
& Hotelling's Trace & 0,152 & 4,946 & 2,000 & 65,000 & 0,010 \\
& Roy's Largest Root & 0,152 & 4,946 & 2,000 & 65,000 & 0,010 \\
\hline
\end{tabular}

Tabel 10 menunjukkan bahwa untuk uji Hotelling's Trace diperoleh nilai $\mathrm{F}=4,946$ dengan $p$ value sebesar 0,010 ( $p$-value $<0,05$ ), sehingga tidak cukup bukti untuk menerima $\mathrm{H}_{0}$. Dengan demikian dapat disimpulkan bahwa terdapat perbedaan signifikan pemahaman konsep dan kemampuan prosedur matematis siswa secara bersama-sama (simultan) antara kelas yang mendapat perlakuan blended learning dengan kelas konvensional. Karena $\mathrm{H}_{0}$ ditolak, sehingga perlu dilakukan uji lanjut (posthoc) untuk menyelidiki apakah masing-masing variabel berbeda signifikan untuk kedua kelompok perlakuan (Hipotesis II dan III). Hasil uji lanjut (posthoc) dapat dilihat pada output hasil uji pengaruh antar subjek (test of between-subject effects) pada Tabel 11.

Tabel 11. Hasil Tests of Between-Subjects Effects (Uji Lanjut)

\begin{tabular}{llrrrrr}
\hline \multicolumn{1}{c}{ Sumber Variansi } & Variabel Dependen & df & Mean Square & F & $p$-value \\
\hline $\begin{array}{l}\text { Kelompok } \\
\text { (Blended vs. Konvensional) }\end{array}$ & Pemahaman Konsep & 1 & 82.721 & 7.932 & .006 \\
\cline { 2 - 7 } & Kelancaran Prosedur & 1 & 49.471 & 6.473 & .013 \\
\hline
\end{tabular}

Hasil analisis pada Tabel 11 menunjukkan bahwa terdapat perbedaan signifikan pemahaman konsep antara siswa yang belajar menggunakan model blanded learning dan siswa yang belajar dengan 
pembelajaran konvensial $(\mathrm{F}=7,932 ; p$-value $=0,006)$. Tabel 11 juga menunjukkan bahwa juga terdapat perbedaan signifikan kelancaran prosedur matematis antara siswa yang belajar menggunakan model blended learning dan pembelajaran konvensional $(\mathrm{F}=6,473 ; p$-value $=0,013)$. Jika mencermati ratarata skor pemahaman konsep dan kelancaran prosedur matematis siswa pada Tabel 2 dan Tabel 3, diperoleh informasi bahwa skor pemahamaan konsep dan kelancaran prosedur matematis untuk kelompok siswa yang belajar menggunakan blended learning lebih tinggi daripada kelompok siswa yang belajar secara konvensional. Hasil tersebut juga terkonfirmasi dari hasil analisis inferensia, sehingga dapat disimpulkan bahwa pemahaman konsep dan kelancaran prosedur matematis siswa yang belajar menggunakan model blended learning lebih baik dibandingkan siswa yang hanya belajar menggunakan model konvensional. Hal tersebut sekaligus mengindikasikan bahwa penerapan model blended learning dalam pembelajaran matematika memberikan pengaruh positif terhadap pemahaman konsep dan kelancaran prosedur matematis siswa.

\section{Pembahasan}

Hasil penelitian ini sejalan dengan penelitian yang sebelumnya telah dilakukan oleh Fatwa dan Djunaidi (2015) yang menyatakan bahwa pembelajaran blended learning mampu meningkatkan hasil belajar siswa. Hasil penelitian ini juga sejalan dengan temuan penelitian Setyaningrum (2018), dimana di dalam penelitian tersebut ditemukan bahwa dengan menggunakan model blended learning pemahaman konsep matematika siswa lebih baik dibandingkan dengan pembelajaran tanpa menggunakan blended learning. Selain itu, penelitian lainnya yang dilakukan oleh Pradnyawati et al (2014) juga menunjukkan bahwa pembelajaran blended learning memberikan pengaruh yang positif terhadap motivasi belajar siswa. Dengan motivasi belajar yang baik siswa akan berusaha meningkatkan pemahaman mereka terhadap materi. Dengan pemahaman yang baik tentu siswa akan mampu memperoleh hasil belajar yang baik.

Hasil penelitian menunjukkan bahwa pemahaman konsep dan kelancaran prosedur secara signifikan dipengaruhi oleh pembelajaran yang digunakan. Hasil analisis deskriptif dan analisis varians multivariat (MANOVA) yang telah dilakukan menjadi dasar penarikan kesimpulan bahwa pembelajaran dengan model pembelajaran blended learning memberikan pengaruh yang lebih baik terhadap pemahaman konsep dan kelancaran prosedur matematis bagi siswa kelas VIII SMP Negeri 1 Sukawati dibandingkan dengan pembelajaran konvensional. Hal ini disebabkan karena proses pembelajaran dengan model pembelajaran blended learning dilakukan dalam 2 tahapan. Tahap pertama adalah tahap online. Dalam tahap online ini siswa diberikan ringkasan materi dan video pembelajaran yang sesuai dengan materi yang dibahas. Selain menyimak materi dan video pembelajaran yang telah diberikan, siswa juga mencari materi dari berbagai sumber baik dari buku-buku maupun sumber online seperti $e$ modul yang banyak sekali tersedia di internet. Dengan menggunakan banyak sumber belajar, siswa mudah untuk menemukan makna sebenarnya dari materi yang dibahas dengan menarik kesimpulan dari beberapa sumber belajar yang diperoleh. Dengan demikian siswa dapat memahami konsep dari materi yang dibahas dengan baik.

Hal lain yang dilakukan dalam tahap online adalah diskusi. Diskusi yang dimaksud adalah percakapan online yang dilakukan oleh siswa baik dengan temannya maupun dengan guru. Dalam diskusi ini siswa diberikan kesempatan untuk mengemukakan pendapat, menyampaikan pemahamannya terkait dengan materi yang dibahas, bertanya tentang materi maupun permasalahan yang belum dipahami, serta menjawab pertanyaan yang diberikan oleh temannya ataupun oleh guru. Pada tahap diskusi ini, jika siswa mengalami kekeliruan dalam memahami suatu konsep, maka siswa lain atau guru dapat langsung memperbaiki pemahaman siswa tersebut dengan memberikan penjelasan atau pemahaman yang benar. Diskusi yang dilakukan dalam pembelajaran online ini dapat dilakukan oleh siswa kapanpun dan dimanapun menggunakan perangkat komputer ataupun handphone mereka masingmasing. Pembelajaran online ini memberikan waktu yang tidak terbatas kepada siswa untuk belajar, mereka dapat mengakses forum diskusi Edmodo kapanpun dan dimanapun meraka inginkan asalkan terdapat perangkat komputer atau handphone serta koneksi internet yang stabil. Pembelajaran seperti ini tentu tidak akan membuat siswa merasa jenuh dalam belajar karena mereka dapat belajar ketika mereka merasa ingin belajar.

Selain membahas materi, dalam diskusi online siswa juga dapat membahas permasalahan atau persoalan-persoalan yang mereka peroleh dari buku maupun dari internet. Soal-soal yang belum bisa diselesaikan atau pembahasan soal yang belum bisa dipahami dengan baik disampaikan oleh siswa 
kemudian siswa lain akan menanggapi permasalahan tersebut. Dalam hal ini siswa dilatih menyelesaikan permasalahan dengan prosedur yang benar agar seluruh siswa yang ikut berdiskusi memahami dengan baik makna dari soal tersebut. Dengan demikian pembelajaran blended learning juga melatih siswa untuk bekerja sama dan berkolaborasi selama proses pembelajaran berlangsung. Hal tersebut tentunya berkontribusi positif terhadap keberlangsungan pembelajaran, dimana siswa yang memiliki kemampuan akademik tinggi diharapkan mampu membimbing siswa lainnya yang memiliki kemampuan akademik sedang dan rendah.

Tahap pembelajaran tatap muka di kelas digunakan untuk mendukung pertemuan online. Pertemuan di kelas digunakan untuk membahas dan mengklarifikasi permasalahan-permasalahan yang muncul dan belum terselesaikan dalam diskusi online serta membahas contoh-contoh soal yang berkaitan dengan materi yang dibahas dengan berbagai macam permasalahan, baik yang disiapkan oleh guru maupun dibawa sendiri oleh siswa. Dengan bantuan pembelajaran online, siswa memiliki waktu yang cukup banyak untuk latihan soal-soal dalam pembelajaran tatap muka. Dalam hal ini siswa memiliki waktu yang cukup banyak untuk berlatih mengerjakan soal-soal dengan berbagai permasalahan menggunakan prosedur yang baik dan benar, agar hasil yang diperoleh sesuai dengan yang diharapkan. Pemahaman konsep yang terbentuk dalam pembelajaran online akan berguna dalam menyelesaikan permasalahan-permasalahan ini. Jika konsep siswa sudah baik dan benar, mereka tidak akan mengalami kesulitan dalam menyelesaikan permasalahan yang diberikan.

Pembelajaran yang dilakukan menggunakan model pembelajaran blended learning menciptakan pembelajaran yang mampu menarik minat siswa dalam belajar serta dapat mendorong siswa menjadi aktif dalam mencari materi dan berdiskusi dengan temannya. Melalui pembelajaran ini siswa digiring untuk aktif menemukan dan memahami pengetahuan dengan membangun pengetahuan mereka sendiri. Ini sesuai dengan teori belajar yang mendasari model pembelajaran blended learning yaitu teori belajar konstuktivisme (individual learning). Individual learning dalam teori ini adalah siswa yang aktif, yang dapat membangun pengetahuan mereka sendiri, secara subjektif, dinamis dan berkembang. Kemudian memproses dan memahami suatu informasi, sehingga siswa mampu menguasai materi pembelajaran secara mandiri. Dengan demikian model blended learning dapat dijadikan sebagai salah satu model untuk meningkatkan prestasi belajar matematika siswa.

\section{SIMPULAN}

Berdasarkan hasil penelitian dan pembahasan yang telah dipaparkan sebelumnya, dapat disimpulkan beberapa hal berikut. Pertama, secara bersama-sama (simultan) pemahaman konsep dan kelancaran prosedur matematis siswa yang belajar dengan model blended learning lebih baik daripada pemahaman konsep dan kelancaran prosedur matematis siswa yang hanya belajar dengan pembelajaran konvensional. Kedua, pemahaman konsep siswa yang belajar dengan model blended learning lebih baik daripada pemahaman konsep siswa yang hanya mengikuti pembelajaran konvensional. Ketiga, kelancaran prosedur matematis siswa yang belajar dengan model blended learning lebih baik daripada kelancaran prosedur matematis siswa yang hanya mengikuti pembelajaran konvensional.

Berdasarkan temuan-temuan yang telah diperoleh pada penelitian ini, dapat diajukan beberapa saran berikut. Pertama, peneliti lain disarankan agar mengujicobakan pengaruh model pembelajaran ini pada aspek pembelajaran yang berbeda, misalnya kemandirian belajar dan kemampuan komunikasi matematika. Kedua, kepada praktisi pendidikan matematika, khususnya guru mata pelajaran matematika diharapkan dalam pembelajaran di kelas untuk menerapkan model pembelajaran blended learning sebagai salah satu alternatif pembelajaran yang inovatif

\section{DAFTAR PUSTAKA}

Adas, D., \& Shmais, W, A. (2011). Students' perceptions towards blended learning environment using the OCC. An - Najah University Journal for Research (Humanities), 25(6), 1681-1710. Retrieved from https://journals.najah.edu/article/150/

Afrilianto, M. (2012). Pembelajaran matematika dengan pendekatan metaphorical thinking untuk meningkatkan pemahaman konsep dan kompetensi strategis matematis siswa. Thesis. Universitas Pendidikan Indonesia, Bandung. 
Akkoyunlu, B., \& Soylu, M. Y. (2008). A study of student's perceptions in a blended learning environment based on different learning styles. Educational Technology \& Society, 11(1), 183193.

Ardana, I. M., Ariawan, I. P. W., \& Divayana, D. G. H. (2016). Development of decision support system to selection of the blended learning platforms for mathematics and ICT learning at SMK TI Udayana. International Journal of Advanced Research in Artificial Intellegence, 5(12). 15-18. doi:https://dx.doi.org/10.14569/IJARAI.2016.051203

Askew, M. (2012). Transforming primary mathematics.New York, NY: Routledge.

Bahr, D. L., \& Garcia, L. A. (2010). Elementary mathematics is anything but elementary: Content and methods from a developmental perspective. Belmont, CA: Wadsworth Cengage Learning.

Balasubramanian, K., Jaykumar, V., \& Fukey, L. N. (2014). A study on "student preference towards the use of Edmodo as a learning platform to create responsible learning environment". ProcediaSocial and Behavioral Sciences, 144, 416-422. doi:https://doi.org/10.1016/j.sbspro.2014.07.311

Brown, R. (2003). Blending learning: Rich experiences from a rich picture. Training and Development in Australia, 30(3), 14-17.

Cramer, K. A., Post, T., \& Currier, S. (1993). Learning and teaching ratio and proportion: Research implications: Middle grades mathematics. In D. Owens (Ed.), Research ideas for the classroom: Middle grades mathematics (pp. 159-178). New York, NY: MacMillan Publishing Company.

Danley, K. (2008). Mathematical proficiency (online). Retrieved form http://www.havasu.k12.az.us/pdf/staff_articles/math_proficiency.pdf

Ekmekçi, E. (2016). Integrating Edmodo into foreign language classes as an assessment tool. Participatory Educational Research (PER), Special Issue (I), 1-11. doi:http://dx.doi.org/10.17275/per.16.spi.1.1

Eryilmaz, M. (2015). The effectiveness of blended learning environments. Contemporary Issues in Education Research, 8(4). 251-256. doi:https://doi.org/10.19030/cier.v8i4.9433

Fatwa, A., \& Djunaidi, D. (2015). Strategi blended learning untuk meningkatkan hasil belajar pokok bahasan persamaan dan fungsi kuadrat mata pelajaran matematika. Electronic Journal Politeknik Harapan Bersama Tegal, 1(1), 46-50. Retrieved from https://ejournal.poltektegal.ac.id/index.php/prosiding/article/view/356

Garrison, R., \& Vaughan, N. (2008). Blended learning in higher education: Framework, principles, and guidelines, San Francisco, CA: Jossey-Bass.

Hermawan, H., Samsuri, S., Kurniawati, D., Sofyaningsih, V., \& Prasetyo, D. (2018). The use of controversial public issues with video and macromedia flash player media in civic education learning. Psychology, Evaluation, and Technology in Educational Research, 1(1), 19-30. doi:http://dx.doi.org/10.33292/petier.v1i1.2

Kementerian Pendidikan dan Kebudayaan Republik Indonesia. (2013). Kerangka dasar Kurikulum 2013. Jakarta: Direktorat Jenderal Pendidikan Dasar dan Menengah Kementerian Pendidikan dan Kebudayaan.

Kilpatrick, J., Swafford, J., \& Findell, B. (2001). Adding it up: Helping children learn mathematics (Mathematics learning study committee). Washington, DC: National Academies Press. doi:https://doi.org/10.17226/9822

Marhendra, A. G., Suryaningtiyas, W., \& Kristanti, F. (2016). Penggunaan model pembelajaran blended learning terhadap hasil belajar matematika kelas VIII di SMPN 38 Surabaya. MUST: Journal of Mathematics Education, Science and Technology, 1(1), 10-20. doi:http://dx.doi.org/10.30651/must.v1i1.97

Mokhtar, F. A. (2016). Rethinking conventional teaching in language learning and proposing edmodo as intervention: A qualitative analysis. Malaysian Online Journal of Educational Technology (MOJET), 4(2), 22-37.

NAEP. (2003). NAEP 2003 Mathematics Report. Retrieved from https://www.education.nh.gov/instruction/assessment/naep/naep11.htm 
National Center for Education Statistics. (2008). Educational technology in U.S. public schools. Retrieved from http://nces.ed.gov/pubsearch/pubsinfo.asp?pubid=2010034

NCTM. (2000). Principles and standards for school mathematics. Reston, VA: Author.

Pradnyawati, L. I., Suparta, I, N., \& Sariyasa, S. (2014). Pengaruh strategi blended learning dalam pembelajaran kooperatif terhadap motivasi belajar matematika ditinjau dari gaya belajar siswa di SMP K 2 Harapan. Jurnal Pendidikan dan Pembelajaran Matematika Indonesia, 3(1), 1-11. doi:http://oldpasca.undiksha.ac.id/e-journal/index.php/JPM/article/view/1356

Quevedo, A. (2011). Blended-learning implementation in undergraduate teacher's formation courses: Difficulties from the students' point of view. The International Journal of Technology, Knowledge, and Society, 7(2), 187-200. doi: http://dx.doi.org/10.18848/1832-3669/CGP/v07i02/56192

Rustiah, R. (2011). Pemahaman konseptual dan pengetahuan prosedur siswa dalam menyelesaikan soal pecahan di kelas VII SMP PGRI 1 Kecamatan Sungai Raya Kepulauan Kabupaten Bengkayang (Skripsi tidak diterbitkan). Universitas Tanjungpura, Pontianak.

Setyaningrum, W. (2018). Blended learning: Does it help students in understanding mathematical concepts? Jurnal Riset Pendidikan Matematika, 5(2), 244-253. doi:https://doi.org/10.21831/jrpm.v5i2.21428

Singh, H., \& Reed, C. (2001). Achieving success with blended learning. American Society for Training and Development, State of The Art Industry Reports 2001. Retrived from https://maken.wikiwijs.nl/userfiles/f7d0e4f0bd466199841ede3eea221261.pdf

Usta, E. (2007). Blended learning and online learning environments: The effect of academic success and satisfaction (Unpublished doctoral dissertation). Gazi University, Ankara.

Van de Walle, J. A. (2008). Elementary and middle school mathematics (S. Suyono, Trans.). Jakarta: Erlangga. (Original work published 2004).

Witherspoon, A. (2011). Edmodo ... A learning management system (Online). Retrieved from http://www.poweredwithtechnology.com/2011/01/edmodoa-learning-management-system.html 